Оксана Шовак

кандидат філологічних наук, доцент, дочент кафедри англійської філології ДВНЗ “Ужгородський Наџіональний Університет” https://orcid.org/0000-0001-6016-7599 Ужгород, Україна, +38 (095)6253015 oksana.shovak@uzhnu.edu.ua

\title{
Thematic groups representing the concept AGE in Modern English
}

Анотація. Стаття присвячена аналізу мовних одиниць, що репрезентують кониепт AGE в сучасній англійській мові. Актуальність наукової розвідки зумовлена загальною спрямованістю сучасної лінгвістики на використання когнітивного підходу до аналізу мовних явищ, а також необхідністю більш детального та глибокого опису концепту AGE, щуо $\epsilon$ унікальним фрагментом мовної картини світу. Метою дослідження $\epsilon$ проведення комплексного аналізу мовних одинищь, що репрезентують кониепт AGE в сучасній англійській мові. Конџепт $A G E$ представлений лексико-семантичним полем «вік», яке, у свою чергу, реалізується за допомогою декількох тематичних груп. Лексичні одиниці, щяо використовуються для побудови кожної з тематичних груп, розділені на 2 групи. Перша представлена лексемами і словосполученнями, що висувають ией віковий період. Друга група складається з одиниць (що належать до різних мовних рівнів), щуо вказують на людину цьього вікового періоду.

Ключові слова: концепт, вік, мовна картина світу, тематична група, синонім, період.

Abstract. The present paper is devoted to the analysis and description of language units, representing the concept AGE in the English language. The topicality of the paper is preconditioned by the general orientation of modern linguistics on the cognitive linguistic approach as well as by the nessessity of a more detailed and profound description of the concept AGE, which is a unique fragment of the linguistic world model. The aim of the research is to provide a comprehensive analysis of the language units, representing the concept AGE in the English language. Concept AGE is represented by lexico-semantic field "age", which in its turn is realized by means of several thematic groups. Lexical units used to construct each of the thematic groups are divided into 2 groups. The first one is represented by lexemes and word-combinations, nominating this age period. Second group is made up of units (belonging to different language levels) pointing to a person of this age period. As a separate group we have also singled out the one, being realized by phraseological units. 
Keywords: concept, realization, thematic group, age, language picture of the world, synonym, period.

Introduction. The rapid development of cognitology and its independent branch - cognitive linguistics, which originated in the international linguistics, is a significant milestone of the paradigm shift in human knowledge (Ray Jackendoff, Mark Johnson, George Lakoff, Ronald Langacker, George Miller, Charles Fillmore, and Wallace Chafe). Modern domestic and Russian linguocognitology is represented by the works of such scholars as V.Z. Demiankov, S.A. Zhabotinska, Y.S. Kubryakova, V.A. Maslova, A.A. Selivanova and others. Western cognitive linguistics is represented by the scientific works of such prominent linguists as E. Rosch, G. Lakoff, H. Putnam, L. Barsalou, V. Evans, G.Fauconnier, R. Gibbs, C. Fillmore, Z. Kovecses, R. Langacker, M. Turner, A.Wierzbicka, and others. Cognitive linguistics operates units special in their nature, which serve as carriers of various kinds of information and are fully or partially materialized in language, rather than language elements. The term "concept" functions as the name of these units. The concepts, being ethno-cultural units of information, reflect the perception of the objects and notions by means of a language.

The present paper is devoted to the analysis and description of language units (and namely thematic groups), representing the concept AGE in the English language. The topicality of the paper is preconditioned by the general orientation of modern linguistics on the cognitive linguistic approach as well as by the nessessity of a more detailed and profound description of the concept AGE, being is a unique fragment of the linguistic world model. The aim of the research is to provide a comprehensive analysis of the language units (and namely thematic groups), representing the concept AGE in the English language.

The methods of the investigation include semantic analysis, the method of dictionary definitions and componential analysis, the analysis of semantic relations between synonyms. The method of semantic field has been used in the process of the systematization and grouping the constituents. In the process of the investigation we have analyzed the sample of nominative units verbalizing the concept AGE taken from lexicographical sources as well as sentences containing nominations of AGE in the texts of fiction which serve as the material for our research.

Results and Discussion. A linguistic sign, that most fully and adequately conveys the content of the concept, acquires the status of the name of the concept. The name of the concept AGE is the noun age. According to Online Etymological Dictionary [5] the noun age dates back to the late 13c., and possesses the meaning "long but indefinite period in human history," from Old French aage (11c., Modern French âge) which means "age; life, lifetime, lifespan; maturity," earlier edage, from Vulgar Latin *aetaticum (source of Spanish edad, Italian eta, Portuguese idade "age"), from Latin aetatem (nominative aetas), "period of life, age, lifetime, years," from aevum "lifetime, eternity, age," from PIE root *aiw- "vital force, life, 
long life, eternity". The meaning "time something has lived, particular length or stage of life" dates back to the early 14 century. The meaning is used especially for "old age" since early $14 \mathrm{c}$. [5].

The lexico-semantic field "age", describing the concept AGE is represented by several thematic groups.

Thematic group "childhood". The lexeme childhood is defined as the time during which one is a child. According to the data of lexico-graphical sources the lexemes childhood and teens are mutually defined. American Heritage Dictionary suggests two meanings of the lexeme childhood, and namely: 1 . The time or state of being a child; 2 . The early stage in the existence or development of something [1]. Functional characteristics of the lexemes representing the thematic group "childhood" varies from 42 (the lexeme childhood) to 2 (the lexeme infant). The lexeme childhood demonstrates the highest quantity of occurrence, being fixed in the texts under analysis 42 times is often used in the texts under analysis.

e.g. He had been her constant companion throughout her childhood, her best friend and later her sweetheart [4, p. 451].

In the text under analysis the lexeme childhood combines adjectives, nouns and verbs.

e.g. Your father and I wanted our children to have a happy childhood without the cares that accompany adulthood [4, p.431].

e.g. She'd been here for less than a year, having spent her childhood running errands for her father in his quest to discover the philosopher's stone [4, p. 230].

Among the synonyms to the lexeme childhood we have also fixed such lexemes as: infancy, schooldays, immaturity, boyhood, girlhood.

The semantic structure of the lexeme infancy (fixed in 14 examples) is represented by 2 meanings: 1 . the state or period of being an infant; 2 .an early stage of growth or development [3].

e.g. "This is my good friend from infancy, Mamadou" [4, p. 234].

The lexeme schooldays (6 examples of usage) denotes the period of your life when you were at school [3].

e.g. I thought with nostalgia of my schooldays [4, p. 221].

Another synonym to the lexeme childhood is immaturity meaning not fully grown or developed [3]. The lexeme has been fixed in the texts under analysis 3 times.

e.g. Even my mother noticed my immaturity; she was always telling me, "Stop staring at people! " [4, p. 341].

The noun babyhood is defined by means of its reference to the noun baby which denotes 1 . a newborn or recently born child; infant; 2 . a newborn or recently born animal [3]. It has been fixed in the texts under analysis 3 times.

e.g. The couple aren't trying to rush Marlowe's babyhood. "We really try to be in the moment, " says Kyle. [4, p.59].

Two lexemes boyhood - the state or time of being a boy and girlhood - the state or time of being a girl [3] are also among the synonyms to the lexeme 
childhood. We have not fixed a single case of using these lexemes in the texts under analysis.

To make a list of lexical units used to describe the thematic field "childhood" we have resorted to different lexico-graphical sources, taking into consideration the part-of-speech appurtenance of the lexeme. The first group is represented by simple (non-derived) words: child, baby; derivatives: childhood, babyhood; compound nouns: newborn etc.

The second group is represented by only 2 word-combinations: first part of life, and early years.

e.g. The tasks of old age are quite different from those tasks of midlife. In the first part of life, the task is getting acquainted with and socialized to society $[4$, p. 65].

e.g. In the early years when he was known as' the Submarine' he avoided attention [4, p. 89].

The description of the thematic group "childhood" would be incomplete without considering the names of the persons denoting an early period of one's life. A detailed analysis of lexico-graphic sources has allowed us to fix the following nouns: babe, baby, kid, bantling, neonate, newborn, bambino, toddler, tot, nursling, suckling, weanling, foundling, sweetling, bratling, papoose, brat, bairn, tiny, youngling, cub, infant, slip, cockerel, boykin, tad, tyke, urchin, quaill, quiff, subdeb, bobby-soxer, gamine, filly, moppet, chickabiddy, nipper, puss, cherub, preteen, guttersnipe; children, fegats, brood, progeniture, progeny, seed, offspring.

We must admit that only some of these words have been fixed in the texts under analysis. Their quantity of their occurrence doesn't exceed 18 examples. The noun babe has been fixed in the texts under analysis 18 times. p.211].

e.g. The babe is healthy, as am I. And Sister Anne shall attend the birth [4,

A bit lower frequency of occurrence is characteristic of the lexeme baby, which was fixed in the texts under consideration 12 times.

e.g. "My dad abandoned us when I was a baby [4, p. 67]. The noun baby demonstrates combinability with the adjectives: small, newborn, lovely, healthy.

The lexeme kid demonstrates frequency of occurrence equivalent to 10 examples.

e.g. "Where is he," the kid asked [4, p. 34].

The noun newborn has been fixed in 8 sentences.

e.g. "It seems like yesterday that Little Hannah was a newborn, " my sister says with a sigh [4, p. 237].

Lower frequency of occurrence is characteristic of the lexeme toddler. It has been fixed in 6 examples.

e.g. She had known it since Jane was a toddler [4, p. 221].

The frequency of the occurrence of the nouns cherub, bambino, chick and infant doesn't exceed 4 cases. 
e.g. The professor had the face of a cherub and arms too long for his squattish body [4, p. 319].

e.g. Poor bambino, " she sympathized, knowing that he had been at least partially correct [4, p.62].

e.g. But he had shared the D with a chick who was not his fiance [4, p.67].

e.g. She had the skin of an infant [4, p.59].

In the course of our analysis we have also come across the adjectives childish, boyish and girlish. We must admit that these adjectives don't characterize the person of such an age period but point to other age periods (childish behaviour, girlish figure, boyish smile). Among other adjectives describing different periods of childhood are: kittenish, new-born, kiddish.

In the course of our analysis we have also come across phraseological wordcombinations describing this period of age/life. All the word-combinations may be divided into two groups: those nominating this period of life: early years/ life, school-going age) and word-combinations, describing the persons representing this age period: (little one, babe in arms, rug rat, in long clothes). The central elements of these word-combinations are nouns that is why we consider them as substantive word-combination. p.67].

e.g. They didn't shoot many deer up here in the early years, did they?" [4,

e.g. All my early life I looked out toward Hog Island and beyond [2, p.111].

e.g. " Little Angel! " said Grandma Henri. My face was puffy [4, p.116].

e.g. He is a kid, he is a little darling [2, p.45].

Thematic group "teenage age". The next group we are going to analyze is the thematic group "teenage age". Teenage age is defined as the time of life between thirteen and nineteen years old [3].

The analysis of lexico-graphical sources has revealed that the lexemes adolescence, adolescent and teenage make up the basic units of the description.

One of the basic principles of our description is that of part of speech appurtenance. As the example of simple (non-derived) words describing this group are youth, teen; derivatives are represented by adolescence, teenage, while the group of compound words is represented by such a lexeme as half-grown.

The second group is represented by phraseological word-combinations, such as: school days, not dry behind the ears.

All the lexical units used to represent this thematic group are divided into 2 groups:

1. Abstract nouns, used to actualize this period of life, and namely: adolescence, juvenility, juvenescence, juniority, immaturity, puberty, pubescence.

2. The nouns pointing to a person of this age group: teenager, adolescent, youth, juvenile, teen, bantling, tomboy.

Let us consider the semantic structure of each of the lexemes. The functional characteristics of the lexemes representing this thematic group varies from 7 (the noun adolescence) to 3 (the lexeme teenybopper). 
Collins English Dictionary defines the lexeme adolescence as the period in human development that occurs between the beginning of puberty and adulthood [3]. We must admit that this lexeme is the only one which demonstrates functional characteristics in the texts under analysis. It has been fixed in the texts under consideration 7 times.

In the text under analysis the lexeme combines only the adjectives early and late.

e.g. She developed the problem in early adolescence [2, p. 123].

The lexeme juvenility possesses the meaning - the quality or condition of being juvenile, esp. of being immature [3]. Not a single case of using this lexical unit in the texts under analysis has been fixed.

Two meanings are characteristic of the lexical unit juvenescence, they are: 1. youth or immaturity, 2. the act or process of growing from childhood to youth [3].

The noun juniority possesses the meaning - the state of being junior [3]. It has not been fixed in the texts under analysis.

The noun immaturity is described by means of its reference to the adjective immature, denoting 1. not fully grown or developed and 2. deficient in maturity; lacking wisdom, insight, emotional stability [3].

Collins English dictionary defines puberty as the period at the beginning of adolescence when the sex glands become functional and the secondary sexual characteristics emerge [3]. The lexical unit puberty was not fixed in the texts under analysis as well. Among the lexical units used to nominate the person belonging to this age period, the first place is occupied by the noun teen or teenager. According to [3] both nouns teen and teenager mean an adolescent between age 13 and 19, the lexeme teen being the obsolete form of the noun teenager.

In the texts under consideration the lexeme teenager has been fixed 16 times.

e.g. She looked like a teenager and had an aura of innocence and trustworthiness that put people at ease [4, p. 128].

Among the lexical units combining the lexeme teenager are adjectives young, difficult, angry.

The lexeme adolescent pointing to an adolescent person [3] is a synonym to the lexeme teenager. The lexeme juvenile is described by means of its reference to the adjective juvenile, the semantic structure of which is represented by 2 meanings: 1. young, youthful, or immature; 2. suitable or designed for young people [3]. This lexeme was not fixed in the texts under analysis.

Collins English Dictionary defines the noun bantling (4 cases of usage) as a young child; brat [3].

e.g. The bantling wiggled on his lap $[2,189]$. 
The noun tomboy has been used in the texts under analysis 4 times. Its semantic structure is described as a girl who acts or dresses in a boyish way, liking rough outdoor activities [3].

e.g. 'She was the tomboy, the leader into mischief, and wherever she went, I willingly followed [4, p.221].

Among the other lexical units representing this thematic field are teenybopper, lad, lass, stripling.

The noun lass (9 cases of usage) pointing to a girl or young woman [3] doesn't demonstrate a high quantity of occurrence.

e.g. "Well, now, the lass speaks the truth, " Lach interrupted, moving his stool over [4, p.239].

The lexeme lad (5 cases of usage) points to a young man [3].

e.g. Two men were lifting a boy up to a window near the door. The lad opened the latch and slipped inside [4, p.32].

The lexeme stripling has been fixed in the texts under analysis 4 times. It is synonymous to the lexeme lad.

e.g. The stripling hurried to her side, and she reached feebly for him [2, p.167].

Among the adjectives used to describe this age period are the following: adolescent, juvenile, juvenescent, teenage, teen, pubescent, half-grown, infantine, blossoming, beardless, green, awkward.

Thus, we have made an attempt to consider those lexical units which represent the thematic group "teenage age", that is those the semantic structure of which has either implicitly or explicitly manifested the semes teenage or adolescent.

We have also fixed word-combinations used to describe this age period. Being divided into 2 groups, the first one is represented by word-combinations, nominating teenage period, and namely: (teenage age, awkward age, school days, one's teens, age of puberty etc.). The occurrence of these word-combinations doesn't exceed 3 cases of usage.

e.g. He was a skinny kid at that awkward age, teeth too big for his mouth [2, p.67].

e.g. As soft-spoken as his mom, " Beth said. " At that awkward age. You should have seen how he blushed when I took his jacket [4, p.78].

The second group is represented by only 1 phraseological unit not dry behind the ears [83]. This phraseological unit has been fixed in the course of the analysis of lexico-graphical sources. We haven't fixed a single case of usage this unit in the texts under analysis.

Thematic group "youth". Oxford English Dictionary defines the lexeme youth in the following way: the period between childhood and adult age [6]. The period of life between youth and old age, is usually considered to be from 40 to 60 years of age. On the basis of the lexico-graphic data and definitions of the lexemes 
child, teenage and mature age we came to the conclusion that the youth period occupies the period from 20 to 40 years.

It goes without saying that age limits are very flexible, and because of this the concept AGE is not a rigidly fixed structure, but the continuum and different age periods may overlap and intersect each other. While forming the list of units describing this age period the basic lexeme was the lexeme youth. Functional characteristics of the lexemes representing this age group varies from 38 (the lexeme youth) to 2 (the lexeme character).

The highest frequency of occurrence is characteristic of the lexeme youth which has been fixed in the texts under analysis 38 times.

e.g. ... his eyes lit up with the arrogant innocence of youth [4, p.78].

In the texts under analysis the lexeme youth combines mostly adjectives, among them: early, unhappy, lost etc. Among the verbs combining the lexeme youth we have fixed the following: spent, waist, have etc.

e.g. He had spent his youth reading the sacred texts of Islam and of Christianity [2, p.89].

Being used in the meaning "young person" the lexeme youth combines the whole range of adjectives, and namely male, white, local, educated etc.

Constructing the list of lexical units used to represent this thematic group we take into consideration the part of speech appurtenance and the structure of the lexeme. The considerable part of these units is represented by simple words (young) and derived lexical units (youthfulness). Another part is represented by word-combinations: young blood, salad days. The reflection of youth in our consciousness is very detailed and the units reflecting this age period may be attributed to the early or late youth. Hence, among units, representing youth are: abstract nouns (and word-combinations) denoting this age period: freshness, youthfulness, youngness, bloom etc.; nouns (and word - combinations) denoting a person of this age group: young person, young man, fellow, younker, whippersnapper, young woman, skirt, minx, doll, deb, coed, chick, flapper, youth etc. .

Let us consider each of the lexemes separately.

The lexeme youngness is treated as the the state of being young or youthful [3]. In the texts under consideration it has been fixed 14 times.

The lexeme youthfulness is derived from the lexeme youthful. The semantic structure of the lexeme is represented by the meaning of, relating to, possessing, or characteristic of youth [6]. This lexeme demonstrates a lower quantity of occurrence in comparison to the lexeme youngness. In the texts under consideration it has been fixed only 10 times.

According to Collins English Dictionary the lexeme bloom possesses 2 meanings: 1. a healthy, vigorous, or flourishing condition; prime (esp. in the phrase the bloom of youth) and 2. youthful or healthy rosiness in the cheeks or face; glow [3].

e.g. She was a woman twenty years his junior, a woman in the full bloom of life $[4, \mathrm{p} .145]$. 
We have also fixed the usage of the phrase the bloom of youth in the text under analysis:

e.g. Waking in the other rooms on the second and third floor of the Athletic Club are friends of the bride and groom -- couple friends, friends who have brought especially serious or promising dates -- almost all of whom find themselves acting, at that hour, on a sexual impulse thats unsettlingly strong even for the bloom of youth [2, p. 16].

The lexeme prime ( 5 cases of usage) points to the time when a thing is at its best. Functioning as adjective it demonstrates combinability with the noun years.

e.g. They're not in the prime years of their careers yet. They're still getting better [4, p.341].

The lexeme springtime - the earliest, usually the most attractive, period of the existence of something [3] has not been fixed in the texts of our analysis as well.

Collins English Dictionary considers the lexeme freshness by means of its reference to the adjective fresh. The lexeme freshness has been fixed in the texts under analysis only 3 times. One of the meanings of the lexeme fresh is youthful or inexperienced [3].

e.g. She had always loved the freshness, the cleanness, the sense of birth [4, p.127].

The lexeme juvenescence has 3 meanings, and namely 1 . youth or immaturity, 2. the act or process of growing from childhood to youth; 3. restoration of youth; rejuvenation. The lexeme has not been fixed in the texts under analysis.

At the next stage of our analysis we have made an attempt to describe lexical units denoting a person of this age period.

The noun fellow being used in the texts under analysis 26 times denotes a man or a boy, especially a boyfriend or lover.

e.g. And each of us held by one big hand of this fellow [4, p.75].

The noun fellow demonstrates combinability with adjectives: old, young, big, little, handsome, charming, fine, good, nice, splendid, lucky, poor etc.

e.g. The poor old fellow might have been someone's grandfather [4, p. 78]

We have also fixed the usage of the noun chap, meaning a boy or a guy [3]. The lexeme has been fixed in the texts under analysis 19 times.

e.g. Her husband's a very decent chap [4, p.178].

The combinability of the noun is restricted by adjectives only.

e.g. Paul wasn't a mate yet, but seemed like a good chap, and he was a helluva guitar player, better than anybody around [4, p.320].

According to Collins English Dictionary younker is a young man [3]. The noun younker has been used in the texts under analysis 12 times.

e.g. " Aye, sir! " young Pannabaker, Thermopylae's cockiest " younker, " piped up in reply, scrambling for a long telescope then hopping atop the weather bulwarks for the mizer-mast shrouds [4, p.210]. 
Collins English Dictionary difines the noun guy as a man or youth [3]. The lexeme guy combines predominantly adjectives: friendly, decent, bad etc.

e.g. I do not hurt you, Edna Bradshaw, I am a friendly guy. " [4, p.120]

Oxford English Dictionary considers a cub (9 cases of usage) as a young man, especially one who is awkward or bad-mannered [6].

e.g. His partner, a young cub with a blade of a nose, crowed. " You're a wizard [88, p.132].

In the texts under analysis we have also fixed the lexeme fledgling - a person that is immature, inexperienced, or underdeveloped [3]. The lexeme has been fixed in the texts under analysis 7 times.

e.g. He took another draw, but being a fledgling he became dizzy and tingly [4, p.267].

The lexemes youngster and chick have the meaning a young person, child or youth [72] (being fixed in the texts under analysis 7 times) also demonstrate combinability with adjectives: good, dragtail, freckle-faced etc. p.63].

e.g. Odum's a good youngster. He could work into the job, " I say " [4,

Collins English Dictionary defines the lexeme chick as - a young woman [3].

The lexeme has been fixed in the texts under consideration 7 times.

e.g. She's a great-looking chick [4, p.40].

The lexeme bloke possesses the meaning a young man [3]. The lexeme has been fixed in 5 sentences. It also demonstrates combinability with adjectives predominantly: poor, nice, stubborn etc.

e.g. A stubborn bloke like you who wouldn't let go [4, p.34].

The noun punk, being fixed in the texts under consideration 4 times is used to denote an inexperienced young person [6].

e.g. He probably had a "we'll be watching you, punk " speech ready for me as well [4, p.111].

The noun pup (4 cases of usage) has the meaning a cheeky or arrogant boy or young man [6].

e.g. The pup's head lolled to the side. He was unconscious; Ethan feared he might be dead [4, p.129].

Lexeme minx, being fixed in the texts under considerarion 4 times posseses the meaning a young person [3]. The lexeme $\min x$ also demonstrates combinability with adjectives little, flirtatious, intelligent etc. [4, p.79].

e.g. I swear, Rosamund, you grow into a flirtatious minx, " Thomas declared

Word-combinations describing this age period are: springtime of life, heyday of youth, happy days, tender age/years, became of age, may of life, flower of life.

Conclusions. The name of the concept AGE is represented by the noun age, which represents the core of the concept. The analysis of the etymological data 
revealed that the lexeme is derived from Old French meaning age; life, lifetime, lifespan; maturity. Age periodicity of the concept under analysis is too detailed and the borderline among different periods of one's life is very fussy. Taking this into consideration, a 5-aspect consideration of the concept, being represented by several components. Concept AGE is represented by lexico-semantic field "age", which in its turn is realized by means of several thematic groups. Lexical units used to construct each of the thematic groups are divided into 2 groups. The first one is represented by lexemes and word-combinations, nominating this age period. Second group is made up of units (belonging to different language levels) pointing to a person of this age period. As a separate group we have also singled out the one, being realized by phraseological units. The perspective of the further study might be the comparative analysis of language units verbalizing the concept AGE in English and Ukrainian.

\section{REFERENCES}

1. American Heritage Dictionary of the English Language [Online]. Available from: http://www.yourdictionary.com/age\#americanheritage.

2. Bryan Henry. War Brides. Lake Union Publishing, 2012.

3. Collins English Dictionary [Online] - Available from: https://www.collinsdictionary.com/

4. Johnson, Antony. The Orphan Master's Son. Random House Trade, 2012.

5. Online Etymology Dictionary [Online]. - Available from: http: //www. etymonline.com

6. Oxford English Dictionary [Online]. - Available from: http://www.oxforddictionaries.com 